\title{
MORPHOLOGICAL, PHYSICAL AND THERMAL CHARACTERIZATION OF MICROFIBRILLATED CELLULOSE ${ }^{1}$
}

Elaine Cristiana Lengowski²*, Graciela Inês Bolzon de Muñiz ${ }^{2}$, Alan Sulado de Andrade ${ }^{2}$, Leonardo Coelho Simon $^{3}$ and Silvana Nisgoski ${ }^{2}$

\footnotetext{
${ }^{1}$ Received on 18.12.2016 accepted for publication on 22.03.2018.

${ }^{2}$ Universidade Federal do Paraná, Departamento de Engenharia e Tecnologia Florestal, Curitiba, PR- Brasil. E-mail: <elainelengowski@gmail.com>and <gbmunize@gmail.com>, <alansulato@gmail.com> and <silnis@yahoo.com>.

${ }^{3}$ Universidade de Waterloo200, Departamento de Engenharia Quimica, Waterloo, ON - Canada. E-mail:<leonardo.simon@uwaterloo.ca>. *Corresponding author.
}

\begin{abstract}
The aim of this study was to characterize microfibrillated cellulose (MFC) produced with a Masuko Sangyo Super Masscolloider using bleached and unbleached pulp of Eucalyptus spp. The MFC was characterized regarding morphology (TEM), crystallinity, viscosity, zeta potential and thermal properties (TGA). Regardless of the fiber type, the processing dramatically reduced the dimensions of the material, so as to obtain structures with nanometric dimensions. MFC produced with unbleached pulp preserved the original brown color of the pulp, which may be advantageous for some applications in the packaging sector, while films produced with bleached pulp were more translucent. The MFC showed lower values of viscosity and crystallinity index in relation to cellulosic pulp. The zeta potential was influenced by the type of fiber used. The main thermal transitions in MFC occurred after $200^{\circ} \mathrm{C}$, demonstrating the potential of this material forhigh-temperature applications.
\end{abstract}

Keywords: Cellulosic pulp; Crystallinity index; Thermal degradation.

\section{CARACTERIZAÇÃO MORFOLÓGICA, FÍSICA E TÉRMICA DE CELULOSES MICROFIBRILADAS}

\begin{abstract}
RESUMO-O objetivo deste trabalho foi caracterizar celuloses microfibriladas (CMF) produzidas pelo processo mecânico, através de 10 passesno moinho Super Masscolloider Masuko Sangyo, utilizando polpa kraft industrial branqueada e não branqueada de Eucalyptus spp. A caracterização das CMF foi realizada através da morfologia (MET), cristalinidade, viscosidade, potencial zeta e análise termogravimétrica (TGA). Independentemente do tipo de fibra, o microprocessamento reduziu drasticamente as dimensões do material de modo a ser obtidas estruturas com dimensões de escala nanométrica. A CMF produzida com polpa não branqueada preservou a cor marrom original da polpa, o que pode ser vantajosa para algumas aplicações no setor de embalagem, enquanto que filmes produzidos com polpa branqueada são mais translúcidos. As CMF apresentaram menores valores de viscosidade e índice de cristalinidade em relação a polpa celulósica. O potencial zeta foi influenciado pelo tipo de fibra utilizado para produzir as CMF. As principais transições térmicas nas CMF ocorrem após $200{ }^{\circ} \mathrm{C}$, demonstrando o potencial desse material em aplicações com temperatura elevada.
\end{abstract}

Palavras-Chave: Polpa celulósica;índice de cristalinidade; Degradação térmica.

Revista Árvore. 2018;42(1):e420113 


\section{INTRODUCTION}

There is a growing trend toward developing safer and more sustainable products (Ianuzzi, 2012), through use of materials with low toxicity from renewable sources and/or that are recyclable, to reduce the use of petroleumbased packaging, metal components and other nonrenewable materials in the industrial setting. Another noteworthy aspect is the application of nanotechnology for the development of new materials. Among natural materials, cellulose stands out as a renewable, biodegradable and inexpensive material, while still having excellent physico-mechanical properties. The application of nanoscience to cellulose has led to development of a new class of material called nanocellulose (Klemm et al., 2002, 2005; Chirayil et al., 2014).

According to Fujisawa et al. (2011), this new class of cellulose can be divided into three groups: cellulose nanocrystals (CNC), produced by a chemical process of acid hydrolysis followed by mechanical agitation of the suspension in water; microfibrillated cellulose (MFC), obtained by mechanical disintegration of the cellulose in water; and microfibrillated cellulose (NFC), prepared using a combination of chemical oxidation followed by mechanical processing in water, or only by the mechanical processing.

The use of microfibrilated cellulose (MFC) in the development of composite materials has attracted the attention of researchers because this material has high resistance and rigidity, together with low molecular mass (Siró and Plackett, 2010), high aspect ratio (100 - $150 \mathrm{~nm} \mathrm{mn}^{-1}$ ) (Sehaqui et al., 2011; Lavoine et al., 2012) (10 - $\left.100 \mathrm{~m}^{2} \mathrm{~g}^{-1}\right)$ and lower crystallinity (Rebouillat and Pla, 2013). These results suggest that small amounts, when used as additives, can result in significant gains in physical-mechanical properties (Rebouillat and Pla, 2013; Lehmonen et al., 2017) as well as the possibility of producing thin films with high transparency and resistance (Dufresne, 2008).

Research in the packaging sector has pointed to MFC as promising materials in the development of modern packaging without the presence of petroleum derivatives, such as for so-called intelligent packaging, which detects the degree of degradation of food by changing color; and biodegradable packaging with good barrier properties for oxygen, oils, and moisture (Dufresne, 2008; Eichhorn et al., 2010; Belbekhouche et al., 2011; Kajanto and Kosonen, 2012; Gonzalez et al., 2012;

Revista Árvore. 2018;42(1):e420113
Rebouillat and Pla, 2013; Kim et al., 2015; Rampazzo et al., 2017; IreanaYusra et al., 2018; Missio et al., 2018).

MFC is used in the paper industry to increase print density or to modify its surface retention capacity (Luu et al., 2011; Brodin et al., 2014) and to improve the physico-mechanical properties (Hassan et al., 2011; Gonzalez et al., 2012; Lengowski and Bonfatti Junior, 2017). In composite production, microfibrils have attracted interest as coatings and films because of their high specific surface area, renewability and good mechanical properties (Spence et al., 2010). In addition, research into MFC in wood panels has been increasing (Taipale et al., 2010; Castro et al., 2017; Lehmonen et al., 2017).

According to Cowie et al. (2014) the world's annual potential market for a diverse range of applications is estimated at 32.8 million metric tons, based on current market data and considering an average penetration estimate. The largest use of nanocellulose is in the paper industry, for film coatings (5.3 million tons), replacement of plastic packaging (4.1 million tons), replacement of plastic films (3.3 million tons), paper filling (2.4 million tons), packaging filling ( 2.4 million tons) and paper coatings (2.2 million tons).

According to the BBC Research Report (2015), the global nanocellulose market was worth 46.8 million dollars in 2014, projected to reach 277.7 million dollars in 2019 , with a compound annual growth rate (CAGR) of $42.8 \%$ by 2019 . Specifically, cellulose nanocrystals had a market worth 28.2 million dollars in 2014, estimated to grow to 158.3 million dollars in 2019 .

Considering these aspects, the main objective of this study was to evaluate the quality of MFC produced from bleached and unbleached industrial kraft pulp of Eucalyptus spp., by analysis of the physical, morphological and thermal properties.

\section{MATERIALAND METHODS}

\subsection{Material}

Industrial kraft pulp of Eucalyptus spp. was used for the production of bleached and unbleached MFC. A suspension of cellulosic pulp and water at $1 \%$ consistency was prepared by homogenization in a blender. After that, the suspension of cellulosic pulp was processed with Masuko Sangyo Super Masscolloider according to Magalhães et al. (2017), obtaining a 
suspension with gel appearance in water. The parameters adopted to obtain the cellulose microfibrils were: rotation frequency of $1,500 \mathrm{rpm}$ and 10 passes through the mill with the mentioned consistency.

\subsection{METHODS}

\subsubsection{Residual lignin and viscosity of cellulosic pulps}

The kappa number represents the degree of delignification of cellulosic pulp and was determined by the TAPPI T236 om-99 standard. This parameter of the bleached and unbleached pulps was determined before and after the MFC production process. The kappa number of the unbleached pulp and unbleached MFC was measured after the delignification, as recommended by the TAPPI T 230 om-04 standard, to verify if they had a suitable degree of delignification for viscosity analysis.

The viscosity was determined according to TAPPI Standard T 230 om-04. To meet the requirements of this standard, pulp and MFC with a kappa number above 35 passed through two equal steps of delignification, with $10 \%$ loading of sodium chlorite $\left(\mathrm{NaClO}_{2}\right)$ and a buffer solution of sodium acetate $\left(\mathrm{CH}_{3} \mathrm{COONa}\right)$ and acetic acid $\left(\mathrm{CH}_{3} \mathrm{COOH}\right)$ in a system with $10 \%$ consistency. After each bleaching step, the cellulose pulp and MFC were washed with distilled water in abundance to eliminate possible residues. Each delignification cycle was performed in a thermostated bath at $70^{\circ} \mathrm{C}$ for one hour.

\subsubsection{Transmission electron microscopy (TEM) and scanning electron microscopy (SEM)}

A Jeol JEM 1200EXII transmission electron microscope ( 600 thousand $X$ ) was used to observe the MFC suspension diluted to $5 \mathrm{ppm}$ in deionized water and dripped onto the 400 mesh screen surface. The samples were left at room temperature for drying, followed by analysis. To certify the size of the fibrils, three diameter measurements were performed in each micrograph of the MFC.

Since TEM analysis can only be used for nanostructures, cellulose pulps with and without bleaching were previously characterized by SEM. For this purpose, Hitachi TM-1000 and Philips XL 30 microscopes were used.

The MFC suspension was diluted to $200 \mathrm{ppm}$ in deionized water, dripped onto the sample holder surface held in place with conductive tape. The samples were left at room temperature for evaporation of the solvent, forming a nanocellulosic film and then were metallized for better identification of the structures by TEM.

\subsubsection{X-ray diffraction}

For the X-ray diffraction analysis, films with objective weight of $30 \mathrm{gm}^{-2}$ were formed and dried in a paper former at a pressure of $80 \mathrm{kPa}$ and temperature of $90{ }^{\circ} \mathrm{C}$ for 20 minutes.

The determination of the crystallinity index of the samples was performed with a Shimadzu XRD-7000 $\mathrm{X}$-ray diffractometer. The configuration adopted for the analysis was the slotted monochromatormode $(1,1,0.3)$, operating at $40 \mathrm{kV}$ with a current of $20 \mathrm{~mA}$. The velocity adopted was $1 \mathrm{~min}^{-1}$, using Cu-Ká radiation with a wavelength of $0.154 \mathrm{~nm}$. The quality index was determined according to the method proposed by Segal et al. (1959).

\subsubsection{Zeta potencial}

The zeta potential of MFC was determined by the light scattering technique. This analysis allows determining the electrophoretic mobility of charged particles. For this purpose, a NanoBrookZetaPALS analyzer (Brookhaven Intruments Corp.) was used. Beforehand, the nanocellulosic suspensions were diluted to concentration of $200 \mathrm{ppm}$.

\subsubsection{Thermal analysis}

For the thermogravimetric analysis of MFC, SetaramSetsys Evolution TGA/DSC device was used. The analyses were carried out under an oxidizing atmosphere, at a constant flow rate of $20 \mathrm{~mL} \mathrm{~min}-1$, using approximately $10 \mathrm{mg}$ of sample. The temperature ramp adopted was $10^{\circ} \mathrm{C}$ per minute, starting at room temperature and ceasing at $650{ }^{\circ} \mathrm{C}$.

\subsubsection{Statistical analysis}

To compare MFC dimensions, the following tests were performed: Grubb's test to evaluate the occurrence of outliers; Shapiro-Wilktest to evaluate data normality; Levene test to verify the homogeneity of variance; and ANOVA to test the variance. When the equality hypothesis was rejected, the Tukey test was performed. All tests were carried out with the Statgraphics Centurion $\mathrm{XV}$ program at $5 \%$ probability.

Revista Árvore. 2018;42(1):e420113 


\section{RESULTS}

\subsection{Residual lignin and viscosity of cellulosic pulps}

The degree of delignification of the pulps, expressed by the kappa number, indicated values of 1.9 for bleached pulp and 95.9 for the unbleached pulp. Considering the high value of residual lignin in the unbleached pulp, the kappa number values of the bleached and unbleached MFC remained at the same level, with values of 1.9 and 95.5 respectively.

Due to the high residual lignin content of the unbleached pulp, selective delignification was required to reduce the kappa numberto measure the viscosity of the unbleached pulp and MFC. Thus, after delignification, the unbleached pulp and MFC showed kappa numbers of 17.4 and 2.0, respectively.

The average viscosity value of the unbleached pulp was $30.9 \pm 3.2 \mathrm{mPa} . \mathrm{s}$, whereas that of bleached pulp was $16.6 \pm 0.8 \mathrm{mPa}$.s. The viscosity values were

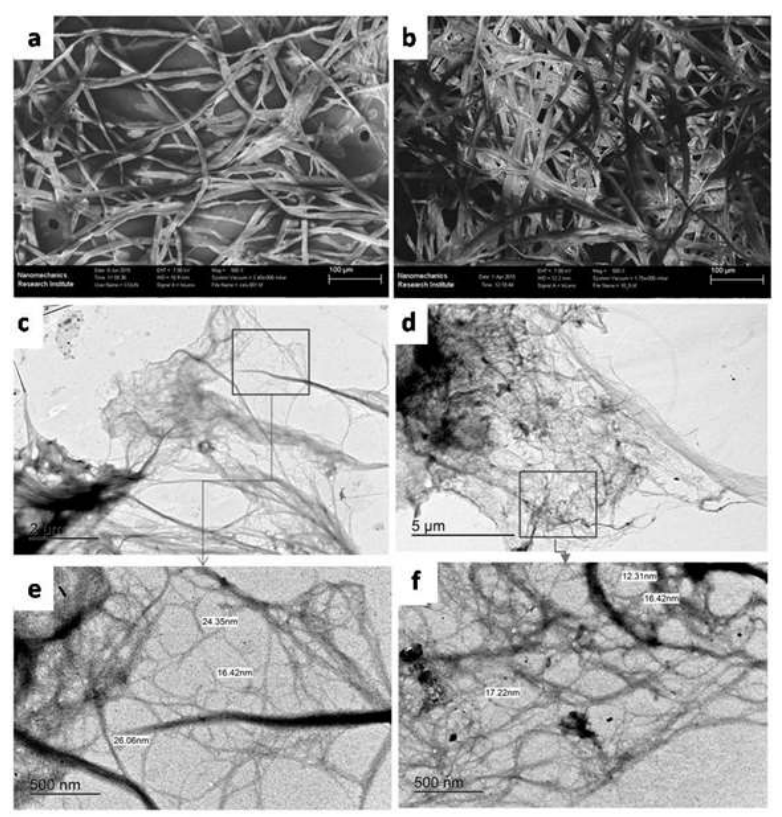

Figure 1 - SEM images. a) Bleached pulp; b) Unbleached pulp. TEM. c) Bleached MFC; d) Unbleached MFC; e) Bleachd MFC with sizing; f) Unbleached MFC with sizing.

Figura 1-MEV. a) Celulose branqueada; b) Celulose não branqueada; MET. c) CMF branqueada; d) CMF não branqueada; e) CMF branqueada com medidas; f) CMF não branqueada com medidas. lower for the MFC samples:3.27 mPa.s for bleached and $3.6 \mathrm{mPa}$.s for unbleached MFC.

\subsection{Transmission electron microscopy (TEM) and scanning electron microscopy (SEM)}

The SEM images of bleached and unbleached pulp before microfibrillation are shown in Figure 1a and Figure 1b, respectively; Figure 1c and Figure 1d show the TEM images of bleached and unbleached MFC; and and Figures 1e and Figure 1f show the TEM images of bleached and unbleached MFC with sizing.

\subsection{X-ray diffraction}

The crystallinity values of the bleached pulp, unbleached pulp, bleached MFC and unbleached MFC were $80.64 \%, 69.22 \%, 70.81 \%$ and $68.44 \%$, respectively.

\subsection{Zeta Potencial}

The average zeta potential values found for bleached MFC were -21.42 mV and -20.27 mV for unbleached MFC. These values indicate the mean suspension stability and flocculation tendency of the samples (Silva, 1999).

\subsection{Thermal analysis}

Figure 2 shows the thermal behavior under inert atmosphere of pulp and MFC samples produced with and without blaching.

Highly ordered cellulose (Type I) began the first thermal decomposition at lower temperatures than the other allomorphs, in the neighborhood of $178^{\circ} \mathrm{C}$. The

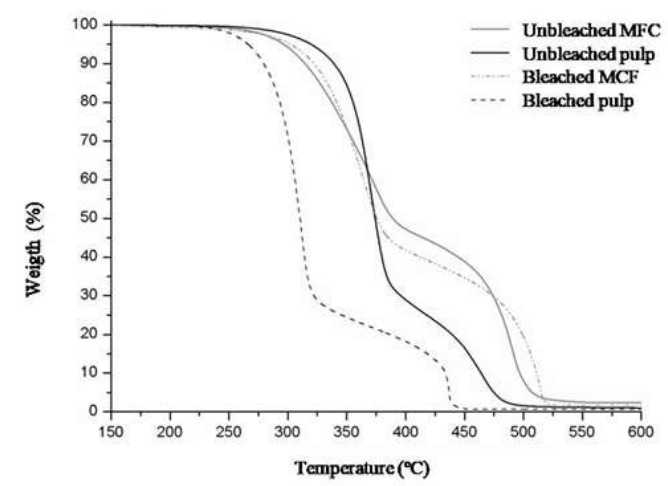

Figure 2 - TGA of bleached and unbleached pulp and MFC. Figura 2-TGA da polpa e CMF com e sem branqueamento.

Revista Árvore. 2018;42(1):e420113 
Table 1- Temperatures of thermal degradation intervals of pulp and MFC.

Tabela 1-Temperaturas dos intervalos de degradação térmica da polpa e das $C M F$.

\begin{tabular}{lcccccc}
\hline \multicolumn{5}{c}{ First degradation } & \multicolumn{3}{c}{$\begin{array}{r}\text { Thermal degradation intervals }\left({ }^{\circ} \mathrm{C}\right) \\
\text { Second degradation }\end{array}$} \\
\hline Sample & Tonset Tmax & Tendset & Tonset & Tmax & Tendset \\
\hline $\begin{array}{l}\text { Unbleached } \\
\text { pulp }\end{array}$ & 275 & 373 & 407 & 429 & 464 & 506 \\
Bleached pulp & 205 & 312 & 350 & 390 & 435 & 456 \\
Unbleached & 248 & 372 & 407 & 440 & 491 & 510 \\
MFC & & & & & & \\
Bleached MFC 261 & 364 & 405 & 455 & 513 & 528 \\
\hline
\end{tabular}

first degradation phase of the cellulosic pulp began at a higher temperature $\left(275^{\circ} \mathrm{C}\right)$ than bleached MFC $\left(261^{\circ} \mathrm{C}\right)$ and unbleached $\mathrm{MFC}\left(248^{\circ} \mathrm{C}\right)$. This behavior trend was also observed for temperature of degradation. The final temperature of the first degradation peak (Tendset) was similar for all the samples $\left(405^{\circ} \mathrm{C}\right.$ and $407^{\circ} \mathrm{C}$ ). In relation to the second degradation peak, the cellulose pulp had the lowest temperature for the start degradation and maximum temperature $\left(429^{\circ} \mathrm{C}\right.$ and $\left.464^{\circ} \mathrm{C}\right)$, followed by unbleached $\mathrm{MFC}\left(440^{\circ} \mathrm{C}\right.$ and $\left.491^{\circ} \mathrm{C}\right)$ and bleached $\mathrm{MFC}\left(455^{\circ} \mathrm{C}\right.$ and $513^{\circ} \mathrm{C}$ $\left.{ }^{\circ} \mathrm{C}\right)$. The bleached MFC had the highest temperature at the end of degradation $\left(528^{\circ} \mathrm{C}\right)$, indicating it was more thermally resistant than the other fibers analyzed (Table 1).

The bleached pulp presented the highest mass loss up to $300^{\circ} \mathrm{C}(28.33 \%)$, followed by unbleached MFC $(9.30 \%)$, bleached MFC (6.49\%) and unbleached pulp with $3.53 \%$ (Table 2). However, MFC had lower total mass loss up to $400^{\circ} \mathrm{C}$, with $62.90 \%$ for unbleached MFC, $63.47 \%$ for bleached MFC followed by unbleached cellulose pulp with $67.63 \%$ mass loss. The bleached pulp had the lowest thermal stability up to that temperature, with mass loss of $81.59 \%$. The bleached cellulose started its degradation peaks at a lower temperature than the other samples, and also presented the lowest maximum and final degradation temperatures. The bleached pulp presented the lowest initial, maximum and final degradation temperatures, and it was not higher than $500{ }^{\circ} \mathrm{C}$ for the second degradation peak.

\section{DISCUSSION}

As expected, the mechanical treatment did not change the kappa number, i.e., the lignin present in the pulp was not mechanically removed.
Table 2 - Mass loss at specified degradation intervals. Tabela 2 - Perda de massa nos intervalos de degradação especificados.

\begin{tabular}{lccccr}
\hline \multirow{2}{*}{ Sample } & \multicolumn{5}{c}{ Weight (\%) } \\
& $100-$ & $200-$ & $300-$ & $400-$ & After \\
& $200^{\circ} \mathrm{C}$ & $300^{\circ} \mathrm{C}$ & $400^{\circ} \mathrm{C}$ & $500^{\circ} \mathrm{C}$ & $500^{\circ} \mathrm{C}$ \\
\hline Unbleached pulp & 0.38 & 3.15 & 64.11 & 3.26 & 29.11 \\
Bleached pulp & 0.25 & 28.08 & 53.26 & 17.53 & 0.88 \\
Unbleached MFC & 0.02 & 6.47 & 56.98 & 3.85 & 32.69 \\
Bleached MFC & 0.19 & 9.11 & 53.60 & 3.85 & 33.25 \\
\hline
\end{tabular}

The average viscosity values of the unbleached and bleached cellulose pulp of Eucalyptus spp. are within what is expected for Eucalyptus spp. kraft pulps (Colodette etal., 2002; Carvalho et al., 2015). The reduction in the viscosity value results from the defibrillation process, which degrades part of the cellulose chains (Iwamoto et al., 2008). The longer the processing time, the greater the size reduction of the cellulosic chains and thus the lower the viscosity is (Abe et al., 2009; Syverud et al., 2011; Viana, 2013).

Potulski (2016) found viscosity values of 48.63 $\mathrm{mPa}$.s for pulp of Eucalyptus spp. delignified to kappa of 3.5 and $14.84 \mathrm{mPa}$.s for the MFC produced with this pulp after 10 passes through the mill. In another study, Potulski (2012) observed a decrease in the viscosity of cellulose pulp of Eucalyptus spp. with kappa 0.4 from $17.3 \mathrm{mPa}$.s to $6.8 \mathrm{mPa}$.s in the production of MFC with 30 passes. The lower values found in relation to the literature may be a result of the bleaching process adopted, with the industrial process being more aggressive than the laboratory delignification carried out by the author, who used delignification performed in four stages with $3 \%$ sodium chlorite $20 \mathrm{~g} \mathrm{~L}^{-1}$ (dry pulp base) and the same volume of buffer solution at a consistency of $10 \mathrm{~g} \mathrm{~kg}^{-1}$ for 1 hour in a water bath at $90{ }^{\circ} \mathrm{C}$.

The mechanical process resulted in defibrillation of the cell wall, producing MFC for both bleached and unbleached pulp, reducing the size of the fibers from the average of $28,000 \mathrm{~nm}$ before processing. The analysis of MFC diameter measures through micrographs revealed that the bleached MFC had an average diameter of $22.28 \pm 5.18 \mathrm{~nm}$ (Figure 1e), while the unbleached MFC had a mean diameter of $15.32 \pm 2.63 \mathrm{~nm}$ (Figure 1f).

Given the large dimensional variability within the sample, these values are statistically the same, but

Revista Árvore. 2018;42(1):e420113 
the presence of lignin did not affect the microfibrillation process, since the production of the nanostructures was possible regardless undergoing bleaching. MFC produced with unbleached pulp was brown and opaque, which is interesting for applications where translucence is not necessary or desired.

Some studies have reported the possibility of producing MFC without bleaching (Spence et al., 2010; Okahisa et al., 2011, Viana, 2013). Spence et al. (2010) found an increase in diameters in MFC from pulps with higher lignin content, unlike found in this work. The authors also emphasized that the use of lignin-containing MFC should reduce production costs, with better use of wood and lower energy and chemical costs since it does not require bleaching.

The process of MFC production is similar to the refining process, and four associated phenomena are described by Coutts (2005): (i) internal fibrillation (IF), where the fiber bundle detaches, resulting in swelling and increased fiber flexibility; (ii) external fibrillation (EF), without complete removal of fibrils; (iii) fibrillar detachment, producing MFC; and (iv) dimensional reduction of the fiber by cutting (FC). These stages were clearly evidenced in the MFC produced, as highlighted in Figure 3.

Kumar et al. (2014), when producing MFC from sugarcane bagasse, hardwood and softwood, found variation in the diameters of the nanofibers, being 12

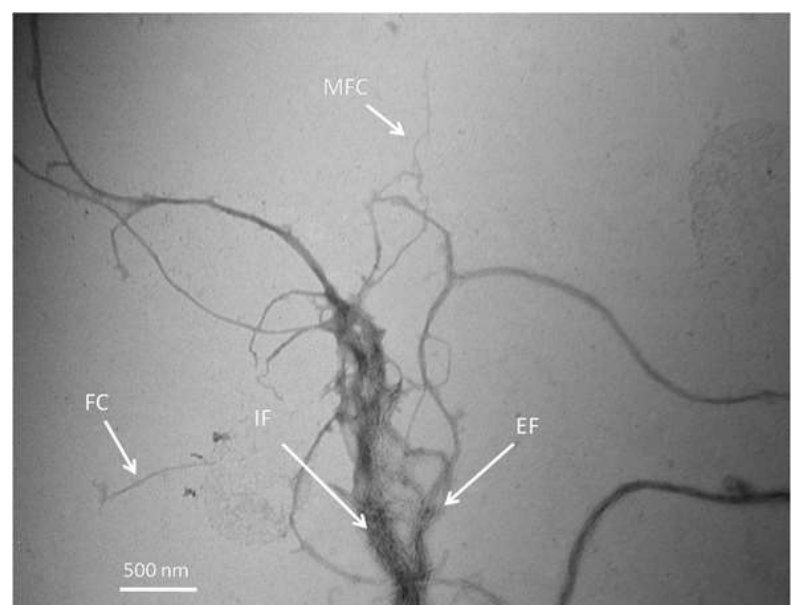

Figure 3 - MFC produced from bleached Eucalyptus spp. pulp with the effects of refining.

Figura 3 - CMF produzida com polpa de Eucalyptus spp. branqueada com os efeitos da refinação. to $75 \mathrm{~nm}, 16$ to $80 \mathrm{~nm}$ and 21 to $97 \mathrm{~nm}$, respectively. This difference occurs mainly due to the production processes used (refining in the PFI mill up to $90{ }^{\circ} \mathrm{SR}$ ) and the nature of the vegetable fibers used.

A weblike distribution of can be observed in MFC. According to Zimmermann et al. (2010), there are numerous hydroxyl groups exposed throughout the microfibrillated cellulose chain, so numerous hydrogen bonds and physical approximations can be performed in order to give the observed weblike appearance. According to Pääkkö et al. (2007), the length of the MFC chains promotes formation of large areas of networks that guarantee numerous intermolecular hydrogen-bonding interactions of these nanofibers. This characteristic generates good results for use as reinforcement in the production of composites (Dufresne et al., 2008).

Besides the loss of viscosity and decrease of the dimensions in relation to the pulp without processing, the degradation of the cellulosic chains can also be observed by the decline in crystallinity. Agreater decrease in crystallinity was observed for bleached MFC over bleached cellulosic pulp. This is because the crystalline regions are affected in the defibrillation process. In general, higher crystallinity values were found for the treatments where the delignification process occurred. The residual presence of lignin and hemicellulose in unbleached MFC may have contributed to the lower crystalline index. Another factor that may have contributed to the lower crystallinity of the unbleached MFC is that the presence of lignin reduced the fiber flexibility, because this component gives rigidity to cell walls, so the crystalline region becomes more susceptible to cleavage of the bonds in the most fragile region in response to mechanical processing.

The results found in this study are similar to those reported by Viana (2013) and Lengowski et al. (2013), $80.8 \%$ crystallinity for unbleached Pinus spp. pulp and $79.22 \%$ for bleached Eucalyptus spp. pulp.

Iwamoto et al. (2007) evaluated the behavior of cellulose processed in the same mill used in this work, with $1,3,5,9,15$ and 30 passes with a rotation of 1500 rpm. They found that the degree of polymerization and the crystallinity index decreased with increasing number of passes through the mill. Since the elasticity of the cellulose depends on the crystalline structure, the decrease of the crystallinity index causes a decrease of the modulus of elasticity of the sheets and of composites that will use the nanocellulose as

Revista Árvore. 2018;42(1):e420113 
reinforcement. There are fewer intermolecular hydrogen bonds between the cellulose molecular chains, a result of the decrease in crystallinity, which causes an increase in the coefficient of thermal expansion of the sheets and composites (Hori et al., 2005).

In general, materials with higher crystallinity indexes are more resistant to thermal degradation. This supposition is based on studies that have shown that amorphous regions of cellulose are more susceptible to heat and have lower thermal stability compared to crystalline regions (Major, 1958; Kim et al., 2010).

The process of fibrillation influences the surface charge of the fibrils. The value found by us was close to that reported by Damásio (2015). This characteristic should be taken into account in the use of the material for production of composites, since it affects the degree of dispersion or agglomeration of MFC. Lu et al. (2014) indicated that high zeta potential values indicate high dispersibility in water while lower values of this parameter indicate low stability.

The unbleached MFC sample presented higher variability. According to Siqueira et al. (2009), differences in MFC dimensions can result in interlacing of the nanocululose fibers, influences the difference in zeta potential values. The presence of residual lignin, responsible for fiber stiffness, may have hampered the dispersion of MFC in the analysis. The presence of residual components of baking in the unbleached MFC may have influenced the reading of the surface charge, since the bleaching process purifies the cellulose by significantly reducing the lignin, hemicellulose and extractive content that are deposited on the surface after kraft cooking. According to Tonoli et al. (2012) and Dufresne et al. (1997), the presence of residual hemicellulose causes a change in this parameter due to its agglutination capacity.

According to the classification proposed by Silva (1999) for colloids, the MFC produced in the laboratory presentedlow stability (potential between $-21 \mathrm{mV}$ and $-30 \mathrm{mV}$ ), indicating the formation of agglomerates.

According to Hubbe (2007), as the refining intensifies, an increase in surface area occurs, making it accessible to cationic polyelectrolytes. However, zeta potential tends to become less negative. Thus, aqueous dispersions of cellulose fibers are influenced in their colloidal stability by the presence of a double electric layer under their surface, resulting from dissociations of different functional groups, such as carboxylic acids, carbonyls and others (Abril and Mogollón, 2012).
As for thermal stability (Table 2), the bleached pulp showed the highest mass loss up to $300^{\circ} \mathrm{C}(28.33 \%)$, followed by unbleached MFC $(9.30 \%)$, bleached MFC (6.49\%) and unbleached pulp (3.53\%). However, MFC had lower total mass loss up to $400^{\circ} \mathrm{C}$, with $62.90 \%$ for unbleached MFC, $63.47 \%$ for bleached MFC, followed by unbleached pulp with $67.63 \%$ mass loss. The bleached pulp had the lowest thermal stability up to that temperature, with mass loss of $81.59 \%$. The degradation peaks of bleached cellulose started at a lower temperature than in the other samples, and also presented the lowest maximum and final degradation temperatures. The bleached pulp presented the lowest initial, maximum and final degradation temperatures, and the second degradation peak was not higher than $500^{\circ} \mathrm{C}$.

The better thermal stability was evidenced by the lower mass loss of MFC and occurred due to the strong and numerous connections formed between fibers. The higher thermal stability of the unbleached pulp is due to the presence of lignin, as indicated by the initial kappa number of the pulps. Degradation occurs in three stages that are characteristic of lignocellulosic materials: loss from 200 to $260^{\circ} \mathrm{C}$, associated with the degradation of hemicelluloses; between 240 and $350{ }^{\circ} \mathrm{C}$, related to cellulose decomposition; and degradation of lignin, the most stable component, which occurs over a wide temperature range, starting at 200 to $500{ }^{\circ} \mathrm{C}$ (Sjöström, 2013; Kawamoto et al., 2015).

Morán et al. (2008) reported that up to $400^{\circ} \mathrm{C}$ almost all cellulose is pyrolyzed, whereas Liao (2003) stated that the peak mass loss for cellulose is subsequent to the thermal degradation of the hemicellulose due to the greater amount of energy required for depolymerization of the cellulose and for breaking the monomers.

The inversion in the thermal stability behavior for the bleached and unbleached MFC after $350^{\circ} \mathrm{C}$ (Figure 2) can be explained because cellulose inhibits lignin depolymerization reactions at temperatures below $300{ }^{\circ} \mathrm{C}$, but this effect disappears at higher temperatures due to degradation of cellulose (Kawamoto et al., 2015). The strong bonds formed by MFC reduce the mass loss after $350^{\circ} \mathrm{C}$ (Lehmonen et al., 2017).

According to Le Van (1992), the thermal degradation of cellulose can be accelerated in the presence of water, acids and oxygen. Therefore, the increase of the temperature in the oxidative atmosphere allows the 
appearance of free radicals that cause the appearance of carbonyl, carboxyl and hydroperoxide groups (White and Dietenberger, 2001; Qingfeng et al., 2005; Ming et al., 2005).

Thermal stability is essential for nanocelluloses to be used as effective reinforcing material. The typical thermoplastic processing temperature is above $200^{\circ} \mathrm{C}$, so the nanocelluloses that are increasingly used as reinforcing agents should be evaluated for their thermomechanical behavior (Hassan et al., 2011; Flauzino Neto et al., 2013; Gonzalez et al., 2012; Lengowski and Bonfatti Junior, 2017).

The reduction of the degree of polymerization as a function of heat treatment is affected by the crystallinity of cellulose (Broido et al., 1973). In general, materials with higher crystallinity indexes are more resistant to thermal degradation. This hypothesis is based on studies showing that amorphous regions of cellulose are more susceptible to heat and have lower thermal stability compared to crystalline regions (Major, 1958; Kim et al., 2010). In the case of crystalline cellulose, the degree of polymerization decreases rapidly without any measurable weight loss until reaching a degree of polymerization near to 400 . On the other hand, amorphous cellulose gradually decreased indegree of polymerization until the formation of monomers or oligomers. Yu and $\mathrm{Wu}$ (2010) reported that amorphous cellulose is more reactive with oligomers and more accessible during hydrolysis due to the low amount of intermolecular hydrogen bonds in this region. However, with the production of MFC there is an increase of the $\mathrm{OH}$ groups available to form interfibrillar bonds, which demand higher energy for rupture, besides producing a film with insulating effect on the passage of air for heat propagation, making the sample more thermally stable in relation to unprocessed cellulose.

Although there is some information about the effect of cellulose crystallinity on its thermal behavior, the influence of this parameter on the formation of liquid intermediates and the distribution of the product of pyrolysis reactions is poorly understood (Wang, 2013).

\section{CONCLUSIONS}

Based on the results presented, it can be concluded that:

- It was possible to produce MFC from bleached and unbleached pulp;

- Defibrillation did not effect of lignin content, in view of the proximity of the kappa numbers of the unbleached pulp and the unbleached MFC;

- After the microfibrillation process there was a marked reduction in the viscosity of the eucalyptus pulp;

- The crystallinity index decreased with microfibrillation;

- MFC samples showed zeta potential with similar values;

- The onset of degradation of unbleached cellulose pulp $\left(200^{\circ} \mathrm{C}-300^{\circ} \mathrm{C}\right)$ occurred at a higher temperature compared to unbleached MFC;

- The bleached MFC presented lower thermal degradation in the range of $200{ }^{\circ} \mathrm{C}-300{ }^{\circ} \mathrm{C}$ in relation to the bleached pulp;

- After $350^{\circ} \mathrm{C}$, the MFC presented greater thermal stability than the cellulosic pulps, especially for the unbleached samples;

- MFC has potential for applications at temperatures up to $200^{\circ} \mathrm{C}$, since it began to be thermally degraded only at temperatures higher than this;

- Unbleached MFC is an interesting material for packaging applications that do not require transparency, since it maintains the initial brown color;

- MFC produced from bleached and unbleached pulps had potential properties for commercial application.

\section{REFERENCES}

Abe K, Nakatsubo F, Yan H. High-strength nanocomposite based on fibrillated chemithermomechanical pulp. Composites Science and Technology. 2009;69(14):2434-7.

Abril A, Mogollón G. Química del papel. In: Zanuttini M. organizador. Reciclado celulósico. Santa Fé: Argentina Riadycip; 2012. p.303-19.

Belbekhouche S, Bras J, Siqueira G, Chappey C, Lebrun L, Khelifi B. et al. Water sorption behavior and gas barrier properties of cellulose whiskers andmicrofibrils films. Carbohydrate Polymer. 2011;83(4):1740-8.

BBC Research. Biomaterial of the future nanocellulose to send market booming with $42.8 \%$ CAGR. Market Research Reports, June 2015.

Revista Árvore. 2018;42(1):e420113 
Avaiable on: https://www.bccresearch.com/ pressroom/avm/biomaterial-of-the-futurenanocellulose-to-send-market-booming-with-42.8percent-cagr

Brodin FW, Gregersen ØW, Syverud K. Cellulose nanofibrils: challenges and possibilities as a paper additive or coating material-a review. Nordic Pulp \& Paper Research Journal. 2014;29(1):156-66.

Broido A, Javier-Son AC, Barrall ED. Molecular weight decrease in the early pyrolysis of crystalline and amorphous cellulose.Journal of Applied Polymer Science.1973;17:3627-35.

Chirayil CJ, MathewL, Thomas S. review of recent research in nano cellulose preparation from different lignocellulosic fibers. Reviews on Advanced Materials Science.2014;37:20-8.

Colodette JL, Gomide JL, Girard R, Jääskeläinen A, Argyropoulos DS. Influence of pulping conditions on eucalyptus kraft pulp yield quality and bleachability. Tappi Journal. 2002;1(1):14-20.

Coutts RSP. A review of Australian research into natural fiber cement composites. Cement and Concrete Composites. 2005;27(5):518-26.

Cowie J,Bilek EM, Wegner TH,Shatkin, JÁ. Market projections of cellulose nanomaterial-enabled products - part 2: volume estimates. TAPPI Journal. 2014;13(6):57-69.

Damásio RAP. Caracterização e aplicações de celuloses nanofibrilada (CNF) e nanocristalina (CNC) [Dissertação].Viçosa, MG: Universidade Federal de Viçosa; 2015.

Carvalho DM, Silva mr, Colodette jl. Estudo da branqueabilidade da polpa kraft de eucalipto. Ciência Florestal. 2015;25(1):185-97.

Castro ML, Claro FC, Magalhães WLE.

Revestimento de painéis MDF com filmes finos de nanocelulose. In: $16^{\circ}$ EVINCI da Embrapa Florestas 25 e 26 jul. 2017, Colombo.Colombo: Embrapa Florestas; 2017.

Dufresne A, Cavaille J, Vignon M. Mechanical behavior of sheets prepared from sugar beet cellulose microfibrils. Journal of Applied Polymer Science. 1997;64(6):1185-94.
Dufresne A. Polysaccharide nano crystal reinforced nanocomposites. Canadian Journal of Chemistry.2008;86:484-94.

Eichhorn SJ, Dufresne A, Aranguren M, Marcovich NE, Capadona JR, Rowan SJ et al. Review: current international research into cellulose nanofibers and nanocomposites. Journal of Material Science.2010;45:1-33.

Fujisawa S, Okita Y, Fukuzumi H, Saito T, Isogai A. Preparation and characterization of Tempooxidized cellulose nanofibril films with free carboxyl groups. Carbohydrate Polymers. 2011;84(1):579-83.

Gonzalez I, Boufi S, Pelach MA, Alcala M, Vilaseca F, Mutje P. Nanofibrillated cellulose as paper additive in Eucalyptus pulps. Bioresources. 2012;7(4):5167-80.

Hassan EA, Hassan ML, Oksman K. Improving bagasse pulp paper sheet properties with microfibrillated cellulose isolated from xylanasetreated bagasse. Wood and Fiber Science. 2011;43(1):76-82.

Hori R, Wada M. The thermal expansion of wood cellulose crystals.Cellulose. 2005;12(5):479

Hubbe MA. Sensing the electrokineticpotencial of cellulosic fiber surfaces Bioresources.

2006;1(1):116-149.

Ianuzzi A. editor. Greener products: the making and marketing of sustainable brands. Boca Raton: CRC Press;2012.

Ireana YusraAF, Juahir H, Nik Ahmad FirdausNW, Bhat AH, Endut A, Abdul Khalil HPS. et al.Controlling of green nanocellulose fiber properties produced by chemo-mechanical treatment process via SEM, TEM, AFM and image analyzer characterization [Internet]. Journal of Fundamental and Applied Sciences. 2018;10(15).doi: 10.4314/jfas.v10i1s.1

Iwamoto S, Nakagaito AN, Yano H. Nanofibrillation of pulp fibers for the processing of transparent nanocomposites. Applied Physics A. 2007;89:461-6.

Iwamoto S, Kentaro A, Yano H. The effect of 
hemicelluloses on wood pulp nanofibrillation and nanofiber network characteristics.

Biomacromolecules. 2008;9(3):1022-6.

Kajanto I, Kosonen M. The potential use of microand nanofibrillated cellulose as a reinforcing element in paper and board based packaging. In: Tappi International Conference on Renewable Materials.5-7 June, 2012. Montreal.

Kawamoto H, Watanabe T, Saka S. Strong interactions during lignin pyrolysis in wood - A study by in situ probing of the radical chain reactions using model dimmers. Journal of Analytical and Applied Pyrolysis 2015;113:630-7.

Kim UJ, Eom SH, Wada M.Thermal decomposition of native cellulose: influence on crystallite size.Polymer Degradation and Stability. 2010;95(5):778-81.

Kim JH, Shim BS, Kim HS, LeeYJ, Min SK, Jang D et al..Review of nanocellulose for sustainable futurematerials. International Journal of Precision Engineering and Manufacturing-Green Technology. 2015;2(2):197-213.

Klemm D, Schmauder H, Heinze T. Cellulose. Biopolymers.2002;6:275-319.

Klemm D, Heublein B, Fink H, Bohn, A. Cellulose: fascinating biopolymer and sustainable raw material.AngewandteChemie International Edition. 2005;44(22):3358-93.

Kumar A, Singh SP, Singh AK. Preparation and characterization of cellulose nanofibers from bleached pulp using a mechanical treatment method. Tappi Journal. 2014;13(5):25-31.

Lavoine N, Desloges I, Dufresne A, Bras J. Microfibrillated cellulose, their barrier properties and applications in cellulosic materials: a review. Carbohydrate Research. 2012;90:735-64.

Lehmonen J, Pere J, Hytonen E, Kangas, H. Effect of cellulose microfibril (MFC) addition on strength properties of middle ply of board. Cellulose. 2017;24(2)1041-55.

Lengowski EC, De Muniz GIB, Nisgoski S, Magalhães WLE. Avaliação de métodos de obtenção de celulose com diferentes graus de cristalinidade. Scientia Forestalis. 2013;41(9):185-94.
Lengowski EC, Bonfatti Junior, EA. Incorporação de amido anfótero e nanocelulose no papel. In: Anais da I Semana de Aperfeiçoamento em Engenharia Florestal da UFPR. I SEAFLOR. Curitiba: Universidade Federal do Paraná; 2017.

Le Van SL. Thermal degradation In: Schniewin D, Arno P. editors. Concise encyclopedia of wood \& wood-based materials.Oxford: Pergamon Press; 1992.

Liao YF. Mechanism study of cellulose pyrolysis [tese]HangZhou:ZheJiang University; 2003.

Lu Q, Tang L, Wang S, Huang B, Chen Y, Chen X. An investigation on the characteristics of celulosenanocrystals from

Pennisetumsínese.Biomass andBioenergy. 2014;70:267-72.

Luu WT, Bousfield DW, Kettle J. Application of nano-fibrillated cellulose as a paper surface treatment for inkjet printing PAPERCON, 2011 Covington.[accessedon: 02 feb 2016] Avaiable:http://wwwtappiorg/Downloads/ Conference-Papers/2011/2011-PaperConConference/11PAP34aspx..

Magalhães WLE, Claro FC, Matos M, Lengowski EC. Produção de nanofibrilas de celulose por desfibrilação mecânica em moinho coloidal.Colombo:EmbrapaFlorestas; 2017.

Major WD. The degradation of cellulose in oxygen and nitrogen at high temperatures [these].Appleton: The Institute of Paper Chemistry; 1958.

Ming G, Biaocan L, Shou Sheng Y, Min Z. Flame retardance of wood treated with guanidine compounds characterized by thermal degradation behavior. Journal of Analytical and Applied Pyrolysis.2005;73:151-6.

Missio AL, Mattos, BD, Ferreira DF, Magalhães WLE, Bertuol DA, GattoDA et al. Nanocellulosetannin films: From trees to sustainable active packaging. Journal of Cleanear Production. 2018;184:143-51.

Morán JI, Alvarez V A, Cyras VP, Vázquez A. Extraction of cellulose and preparation of

Revista Árvore. 2018;42(1):e420113 
nanocellulose from sisal fibers. Cellulose. 2008;15;149-59.

FlauzinoNeto WP, Silvério HA, Dantas NO, Pasquini D. Extraction and characterization of cellulose nanocrystals from agro-industrial residue - Soy hulls. Industrial Crops and Products.2013;42:480-8.

Okahisa Y, Abe K, Nogi M, Nakagaito AN, Nakatani T, Yano H. Effects of delignification in the production of plant-based cellulose nanofibers for optically transparent nanocomposites Composites Science and Technology. 2011;71:1342-7.

Pääkkö M, Ankerfors M,Kosonen H, Nykänen A,Ahola S, Österberg M et al. Enzymatic hydrolysis combined with mechanical shearing and high-pressure homogenization for nanoscale cellulose fibrils and strong gels.

Biomacromolecules. 2007;8(6):1934-41.

Potulski DC. Efeito da incorporação de microfibrilas de celulose sobre as propriedades do papel [dissertação]. Curitiba: Universidade Federal do Paraná; 2012.

Potulski DC. Influência da nanocelulose nas propriedades físicas e mecânicas de papel primário e reciclado de Pinus e Eucalyptus [doutorado]. Curitiba: Universidade Federal do Paraná; 2016.

Qingfeng L, Chunxiang L, Yonggang Y, Fu H, Licheng L. Study on the pyrolysis of woodderived rayon fiber by thermogravimetry-mass spectrometry. Journal of Molecular Structure 2005;733:193-202.

Rampazzo R,Alkan D,Gazzotti S,OrtenziMA,Piva G,Piergiovanni L. Cellulose Nanocrystals from lignocellulosic raw materials; for oxygen barrier coatings on food packaging films. Packaging Technology and Science. 2017. doi: 10.1002/pts.2308.

Rebouillat S, Pla F. State of the art manufacturing and engineering of nanocellulose: A review of available data and industrial applications. Journal of Biomaterials and

Nanobiotechnology.2013;4:165-88.

Sehaqui H, Zhou Q, Ikkala O, Berglund LA.
Strong and tough cellulose nanopaper with high specific surface area and porosity.Biomacromolecules.2011;12:3638-44.

Segal L, Creely JJ, Martin AE, Conrad Segal L, Creely JJ, Martin AE et al. An empirical method for estimating the degree of crystallinity of native cellulose using the X-ray diffractometer.Textile Research Journal. 1959;29(10):786-94.

Silva TSS. Estudo de tratabilidadefisico-química com uso de tanino vegetais em água de abastecimento e esgoto [dissertação]. Fundação Oswaldo Cruz; 1999.

Siqueira G, Bras J, Dufresne A. Cellulose whiskers versus microfibrils: Influence of the nature of the nanoparticle and its surface functionalization on the thermal and mechanical properties of nanocomposites. Biomacromolecules.2009;10:425-32.

Siró I, Plackett D. Microfibrillated cellulose and new nanocomposite materials: a review. Cellulose.2010;17:459-94.

Sjöström E. Wood chemistry fundamentals and applications.New York: Academic Press; 2013.

Spence KL, Venditti RA, Rojas O, Habibi Y, Pawlak J. The effect of chemical composition on microfibrillar cellulose films from wood pulps: water interactions and physical properties for packaging applications. Cellulose. 2010;117:835-48.

Syverud K, Carrasco GC, Toledo J, Toledo PG. A comparative study of Eucalyptus and Pinus radiata pulp fibres as raw materials for production of cellulose nanofibrils. Carbohydrate Polymers. 2011;84(3):1033-8.

Taipale T, Österberg M, Nykänen A, Ruokolainen J, Laine J. Effect of microfibrillated cellulose and fines on the drainage of kraft pulp suspension and paper strength. Cellulose. 2010;17:1005-20.

Technical Association of The Pulp and Paper Industry - TAPPI. T236 om-99. Kappa number of pulp. In: Tappitest methods.Atlanta: TAPPI Press; 1999.

Technical Association of The Pulp and Paper Industry - TAPPI. T230 om-04. Viscosity of pulp: capillary viscometer method. In: Tappitest 
methods.Atlanta:TAPPI Press; 2004.

Tonoli GHD, Teixeira EM, Corrêa AC, Marconcini JM, Caixeta LA, Silva PMA et al. Cellulose micro/ nanofibres from Eucalyptus kraft pulp: Preparation and properties. CarbohydratePolymers. 2012;89:80-8.

Viana LC. Desenvolvimento de filmes celulósicos nanoestruturados a partir da madeira de Pinussp [tese]. Curitiba: Universidade Federal do Paraná; 2013.

Wang Z. Understanding cellulose primary and secondary pyrolysis reactions to enhance the production of anhydrosaccharides and to better predict the composition of carbonaceous residues [these]. Pullman:Washington State University; 2013.
White RH, Dietenberger MA. Wood products: thermal degradation and fire. In: Buschow KHJ, Cahn RW, Flemings MC, Ilschner B, Kramer EJ, Mahajan S. editors. Encyclopedia of materials: science and technology.Amsterdam: Elsevier Science; 2001.

Yu Y, Wu H. Significant differences in the hydrolysis behavior of amorphous and crystalline portions within microcrystalline cellulose in hotcompressed water. Industrial \& Engineering Chemistry Research.2010;49:3902-9.

Zimmermann T, Bordeanu N, Strub E. Properties of nanofibrillated cellulose from different raw materials and its reinforcement potential. Carbohydrate Polymers. 2010;79(4):1086-93. 